\title{
Pelatihan Motivasi Bagi Siswa Kelas XI SMA dalam Mempersiapkan Diri Menghadapi Ujian Nasional
}

\author{
Siti Rahmawati ${ }^{1}$, Rochimah Imawati ${ }^{2}$, Masni Erika Firmiana ${ }^{3}$ \\ ${ }^{1,2,3}$ Program Studi Psikologi, Fakultas Psikologi dan Pendidikan, Universitas Al Azhar Indonesia, \\ Kompleks Masjid Agung Al Azhar, Jl. Sisingamangaraja, Kebayoran Baru Jakarta Selatan, 12110
}

Penulis untuk Korespondensi/E-mail: siti_rahmawati@uai.ac.id

\begin{abstract}
Abstrak - Ujian Nasional (selanjutnya disebut UN) seperti menjadi semacam momok yang sangat menakutkan bagi kebanyakan peserta didik di seluruh Indonesia. Tak jarang sebagian dari mereka mengalami psikosomatis sebelum menjalani UN. Kondisi seperti kecemasan, motivasi mendadak turun, tidak jarang terjadi hingga mengacaukan tujuan mereka : lulus UN. Pelatihan ini diberikan untuk meningkatkan motivasi dengan memberikan treatment berupa test minat dan bakat, serta training motivasi untuk mennetukan setting goal siswa untuk menentukan cita-cita. Setelah mengikuti pelatihan ini siswa-siswa mampu lebih mengenal diri mereka dan potensi-potensi yang dimiliki. Siswa juga merasa lebih percaya diri dan siap untuk menghadapi UN. Rasa cemas yang sering muncul dapat berkurang karena siswa sudah mampu mengidentifikasi kelebihan dan kekurangan yang ada ada dirinya.
\end{abstract}

\section{Kata Kunci - Pengaturan Tujuan, Masa Remaja, Motivasi, Training, Ujian Nasional}

Abstract - The National Examination (hereinafter referred to as UN) is like becoming a scary specter for most learners throughout Indonesia. Not infrequently some of them experience psychosomatic before doing UN. Conditions such as anxiety, sudden motivation down, not infrequently happens to disrupt their goals: pass the UN. This training is given to improve motivation by providing treatment in the form of test of interest and talent, as well as motivational training to determine the goal setting of students to determine the ideals. After attending this training the students are able to know more about themselves and their potentials. Students also feel more confident and ready to face the UN. Anxiety that often appears can be reduced because students are able to identify the advantages and disadvantages that exist there himself.

Keywords - Goal Setting, Adolescence, Motivation, Training, National Examination

\section{PENDAHULUAN}

$\mathrm{U}$ Jian Nasional (selanjutnya disingkat menjadi UN) merupakan satu tahapan yang menentukan bagi siswa baik SD, SMP maupun SMA untuk melanjutkan pendidikan ke tahapan selanjutnya. Badan Nasional Standar Pendidikan mendefinisikan UN sebagai "kegiatan pengukuran dan penilaian kompetensi peserta didik secara nasional pada jenjang pendidikan menengah". Selanjutnya, hasil UN digunakan sebagai salah satu pertimbangan untuk pemetaan mutu satuan dan/atau program pendidikan; dasar seleksi masuk jenjang pendidikan berikutnya; penentuan kelulusan peserta didik dari program dan/atau satuan pendidikan dan pembinaan serta pemberian bantuan kepada satuan pendidikan dalam upaya peningkatan mutu pendidikan (BSNP, 2008). Marantika (2003) menyatakan bahwa Ujian Nasional merupakan alat untuk mengukur seberapa jauh penguasaan siswa atas materi pelajaran yang telah dipelajari selama kurun waktu tertentu.

Meski bertujuan baik, namun dalam pelaksanaannya, UN menimbulkan berbagai macam repon, terutama dari para siswa. Sejak duduk di tingkat akhir SD, siswa diharapkan mampu memberikan hasil terbaik dalam UN 
yang dijalani. Hal ini berlanjut hingga SMP bahkan SMA. Pihak-pihak, seperti guru dan orang tua tanpa sadar memiliki tuntutan yang besar kepada siswa, tak jarang hal ini berubah menjadi tekanan yang harus dipenuhi oleh siswa-siswa tersebut. Pada masa SMA, tekanan ini menjadi lebih besar karena lulus SMA merupakan landasan untuk karir di masa selanjutnya, yaitu meneruskan ke Perguruan Tinggi. Tekanan tersebut menimbulkan rasa cemas bagi para siswa, terutama ketika karena menghadapi bermacam-macam persiapan untuk menghadapi UN seperti pengulangan materi di sekolah (remedial), mengikuti bimbingan belajar (bimbel) serta serangkaian ujian lainnya, termasuk ujian tertulis, praktek, bahkan ujian lokal sekolah. Hal ini belum termasuk sejumlah uji coba (try out) yang biasa dilakukan bekerja sama dengan lembagalembaga di luar sekolah. Selanjutnya ujian yang paling menakutkan bahkan menjadi momok bagi para siswa tingkat akhir adalah Ujian Nasional (UN). Tak jarang muncul berbagai berita tentang siswa yang bunuh diri karena gagal dalam UN, atau karena takut tidak lulus dalam UN (http://megapolitan.kompas.com; http://www.edisicetak.joglosemar.co ).

Kecemasan dapat memecah belah pemikiran seseorang, membagi dua pikiran seseorang menjadi niat yang baik dan pemikiranpemikiran yang buruk. Tuntutan yang tinggi dan kompetesi yang ketat dapat menimbulkan pesimisme, dimana siswa kehilangan self efficacy dan locus of controlnya. Hal ini sangat mungkin memunculkan sejumlah hal tertentu dalam menghadapi ujian tersebut. Untuk itu siswa SMA perlu diberikan persiapan secara psikologis untuk menghadapi UN yang sering dianggap sebagai salah satu momok paling menakutkan. Strategi yang digunakan adalah dengan memberikan training motivasi menghadapi UN. Mengingat tekanan tersebut akan lebih tinggi pada siswa kelas XII (seperti ujian-ujian, bimbel yang lebih intens, remedial, serta try out), maka selayaknya training motivasi diberikan sebelumnya (kelas XI).

Faktor kecemasan dalam Ujian Nasional dapat disebabkan oleh beberapa faktor, diantaranya oleh kondisi dan situasi saat ujian berlangsung meski materi pelajaran yang akan diujikan telah dikuasai-, waktu yang terbatas, tingkat kesulitan materi ujian, instruksi tes, bentuk pertanyaan dan hal-hal teknis lainnya; semakin meningkat ketika banyak rekan sesama siwa yang tidak lulus ujian. Faktor lain yang juga dapat berpengaruh adalah kurangnya percaya diri atas kemampuan yang dimiliki. Kurangnya rasa percaya diri dapat menyebabkan siswa justru melakukan tindakan yang tidak seharusnya dilakukan seperti menyontek, mencari bocoran jawaban, dan lain-lain.

Berdasarkan hal tersebut, maka kegiatan pelatihan ini dirasa perlu guna memberikan pemahaman dan informasi mengenai potensi yang dimiliki oleh siswa sekaligus mempersiapkan diri menghadapi UN, termasuk mengatasi kecemasan. Pelaksanaan kegiatan ini diawali dengan tes minat bakat, dilanjutkan dengan pengenalan diri dan kompetensi, sharing session, self efficacy, pemberian motivasi dan goal setting

\section{KERANGKA TEORI}

\section{Goal Setting}

Tujuan atau goal adalah suatu hasil atau keadaan ideal yang diinginkan seorang individu dimana individu akan bekerja atau berusaha demi terwujudnya hasil tersebut, dan memiliki nilai tersendiri bagi orang tersebut. Goal sangat penting karena merupakan panduan dari tindakan yang akan dilakukan karena goal mengarahkan, menyalurkan dan menetapkan apa yang harus dilakukan. Goal juga memotivasi perilaku karena goal adalah bentuk dari motivator dan penyemangat. Tanpa adanya goal maka tidak mungkin ada motivasi. Selain itu, goal juga memberikan dasar dalam pemecahan masalah dalam diri maupun dalam kelompok dan goal adalah syarat mutlak untuk penilaian dan evaluasi. Tanpa mengetahui apa tujuan dari tindakan yang dilakukan, maka tidak mungkin penilaian dapat dilakukan (Johnson \& Johnson, 2006).

Menurut Teori Goal, orientasi goal memberikan kerangka untuk memperkirakan dan bereaksi terhadap suatu kejadian (Dweck \& Leggett, 1988 dalam Boon, 2007), serta mempengaruhi perilaku yang mendukung pencapaian (Elliot \& Church, 1997 dalam Boon, 2007). Goal menentukan keahlian dan performa, kadang merujuk pada tugas dan kemampuan. Teori Goal menyatakan bahwa siswa yang mampu mengadopsi keahlian atau orientasi goal tugas lebih termotivasi untuk berhasrat belajar untuk mengembangkan 
kemampuan dan keahlian mereka dalam menyelesaikan tugas. Sementara siswa yang memiliki performa orientasi goal akan termotivasi untuk berhasrat belajar untuk menunjukkan kemampuan dan kebisaan. Secara umum, keahlian dalam menentukan goal sering dihubungkan dengan kognisi positif, motivasional, afektif dan hasil perilaku, sedangkan performa goal sering dihubungkan dengan kurangnya respon adaptif (Ames, 1992; Dweck \& Leggett, 1988 dalam Boon, 2007).

\section{Evaluasi Pelatihan}

Model evaluasi Kirkpatrick merupakan model evaluasi pelatihan yang dikembangkan pertama kali oleh Donald L. Kirkpatrick pada tahun 1959 (Kirkpatrick \& Kirkpatrick, 2007) dengan menggunakan empat level dalam mengkategorikan hasil-hasil pelatihan. Empat level tersebut adalah level reaksi, pembelajaran, perilaku dan hasil. Level pertama adalah reaksi. Reaksi dilakukan untuk mengukur tingkat reaksi yang didisain agar mengetahui opini dari para peserta pelatihan mengenai program pelatihan. Evaluasi reaksi ini sama halnya dengan mengukur tingkat kepuasan peserta pelatihan. Untuk mengukur tingkat kepuasan terhadap pelatihan ini, biasanya diiringi dengan isian tentang instruktur /pelatih, fasilitas pelatihan, materi pelatihan, hingga konsumsi yang disediakan selama pelatihan.

Level kedua adalah pembelajaran. Level ini dilakukan untuk mengetahui sejauh mana daya serap peserta program pelatihan pada materi pelatihan yang telah diberikan. Evaluasi pada level ini, untuk mengetahui sejauh mana daya serap peserta program pelatihan pada materi pelatihan yang telah diberikan, dan juga dapat mengetahui dampak dari program pelatihan yang diikuti para peserta dalam hal peningkatan knowledge, skill dan attitude mengenai hal -hal yang dipelajari dalam pelatihan. Oleh karena itu diperlukan tes untuk mengetahui kesungguhan apakah para peserta mengikuti dan memperhatikan materi pelatihan yang diberikan. Data evaluasi diperoleh dengan membandingkan hasil dari pengukuran sebelum pelatihan atau tes awal (pre-test) dan sesudah pelatihan atau tes akhir (post test) dari setiap peserta. Pertanyaan-pertanyaan disusun sedemikian rupa sehingga mencakup semua isi materi dari pelatihan.
Level ketiga adalah perilaku. Pada level ini diharapkan setelah mengikuti pelatihan terjadi perubahan tingkah laku peserta pelatihan dalam melakukan pekerjaannya. Selain itu juga untuk mengetahui apakah pengetahuan, keahlian dan sikap yang baru sebagai dampak dari program pelatihan, benar-benar dimanfaatkan dan diaplikasikan di dalam perilaku sehari-hari dan berpengaruh secara signifikan terhadap peningkatan kompetensi. Level terakhir adalah result (hasil), yang dilakukan untuk menguji dampak pelatihan terhadap target grup secara keseluruhan. Pelatihan yang dilaksanakan ini hanya sampai pada tahap 1 karena keterbatasan waktu.

\section{METODE PENELITIAN}

\section{Metode Penelitian}

Metode penelitian yang digunakan dalam penelitian ini adalah kualitatif. Bogdan dan Taylor (1975: 5, dalam Moleong, 2013: 4) mendefinisikannya sebagai prosedur penelitian yang menghasilkan data deskriptif berupa katakata tertulis atau lisan dari orang-orang dan perilaku yang dapat diamati. Pendekatan ini diarahkan pada latar dan individu tersebut secara holistik (utuh). Jadi, dalam hal ini tidak boleh mengisolasikan individu atau organisasi ke dalam variabel atau hipotesis, tetapi perlu memandangnya sebagai bagian dari sesuatu keutuhan. Sementara Kirk dan Miller (1986:9, dalam Moleong, 2013: 4) mendefinisikan penelitian kuliatatif sebagai sebuah tradisi tertentu dalam ilmu pengetahuan sosial yang secara fundamental bergantung dari pengamatan pada manusia baik dalam kawasannya maupun dalam perisitilahannya. Sementara menurut Denzin dan Lincoln (2009) penelitian kualitatif adalah penelitian yang menggunakan latar alamiah, dengan maksud menafsirkan fenomena yang terjadi dan dilakukan dengan jalan melibatkan berbagai metode yang ada. Penelitian kualitatif adalah penelitian yang menghasilkan dan mengolah data yang sifatnya deskriptif seperti transkripsi wawancara, catatan lapangan, gambar, foto, rekaman video, dan lain sebagainya (Sarantakos, 1993 dalam Poerwandari, 2007) . Berdasarkan sejumlah definisi tersebut, dapat dijelaskan bahwa penelitian kualitatif ini tidak menghasilkan dan mengolah data yang sifatnya non deskriptif (berupa angka). Penelitian pun dilakukan dalam latar alamiah, di tempat subjek 
sendiri. Dalam penelitian ini, peneliti akan mengumpulkan dan mengolah data yang berupa hasil wawancara awal dari alumni SMA bersangkutan, dan Focus Group Discussion (FGD) dengan peserta pelatihan.

\section{Subjek Penelitian}

Subjek dalam penelitian ini adalah 3 (tiga) orang alumni SMA Plus Dharma Karya yang memberikan informasi mengenai kondisi adikadik kelasnya serta berdasar pengalaman mereka saat masih duduk di bangku kelas XI. Selain itu subjek lainnya adalah peserta pelatihan yang berjumlah 90 (sembilan puluh) orang.

\section{Teknik Pengumpulan Data}

Dalam penelitian ini,tim melakukan pengumpulan data dengan menggunakan 2 (dua) cara, yaitu observasi, dan wawancara.

\section{a. Observasi}

Observasi adalah suatu proses melihat, mengamati dan mencermati serta merekam perilaku secara sistematis untuk suatu tujuan tertentu (Banister, 1994, dalam Herdiansyah, 2010 :131). Observasi juga dikatakan sebagai suatu kegiatan mencari data yang dapat digunakan untuk memberikan suatu kesimpulan atau diagnosis. Sementara Patton mengatakan observasi merupakan metode pengumpulan data esensial dalam penelitian, apalagi penelitian dengan pendekatan kualitatif (Patton, 1990, dalam Poerwandari, 2007).

Inti dari observasi adalah adanya perilaku yang tampak dan adanya tujuan yang ingin dicapai. Perilaku yang tampak dapat berupa perilaku yang dapat dilihat langsung oleh mata, dapat didengar, dapat dihitung dan dapat diukur. Selain itu, observasi haruslah mempunyai tujuan tertentu. Pada dasarnya, tujuan dari observasi adalah untuk mendeskripsikan lingkungan yang diamati, aktivitas-aktivitas yang berlangsung, individu-indvidu yang terlibat dalam lingkungan tersebut, beserta aktivitas dan perilaku yang dimunculkan, serta makna kejadian berdasarkan perspektif individu yang terlibat tersebut (Herdiansyah, 2010 : 132). Dalam kegiatan ini, observasi lebih banyak dilakukan saat FGD, dan pelaksanaan kegiatan. Dalam menyampaikan pendapat, para subjek terlihat banyak yang malu-malu, serta memiliki kepercayaan diri yang kurang memadai. b. Wawancara

Wawancara adalah percakapan dan tanya jawab yang diarahkan untuk mencapai tujuan tertentu (Banister dkk,1994, dalam Poerwandari, 2007). Sedangkan menurut Moleong (2005, dalam Herdiansyah, 2010), wawancara adalah percakapan dengan maksud tertentu. Lalu Gorden (dalam Herdiansyah, 2010) mendefinisikan wawancara sebagai percakapan antara dua orang yang salah satunya bertujuan untuk menggali dan mendapatkan informasi untuuk suatu tujuan tertentu. Berdasarkan tiga definisi tersebut, maka wawancara dalam penelitian ini bermaksud untuk mengumpulkan data yang berhubungan dengan kepercayaan diri, goal setting, serta motivasi para peserta kegiatan. Mengingat waktu yang cukup terbatas, maka wawancara dilakukan dengan teknik FGD.

\section{Metode Analisa Data}

Analisis data kualitatif adalah upaya yang dilakukan dengan jalan bekerja dengan data, mengorganisasikan data, memilah-milahnya menjadi satuan yang dapat dikelola, mensitensiskannya, mencari dan menemukan pola, menemukan apa yang penting dan apa yang dipelajari dan memutuskan apa yang dapat diceritakan kepada orang lain (Bogdan \& Biklen, 1982 dalam Moleong 2013:248). Analisis data, menurut Patton (2009) adalah proses mengatur urutan data, mengorganisasikannya ke dalam pola, kategori dan satuan uraian dasar.

Poerwandari (2007) menyatakan bahwa tahap metode analisa data meliputi:

1. Membaca berulang-ulang data mentah

2. Koding

3. Melakukan Kategorisasi / pengelompokan Dalam kegiatan ini analisis data awal dilakukan untuk data yang bersumber dari 3 (tiga) orang alumni. Sejumlah data yang diperoleh kemudian dikoding dan dikategorisasi.

\section{Penafsiran Data}

Menurut Schaltzman dan Strauss (1973 : 110 111, dalam Moleong, 2013: 257), tujuan yang akan dicapai dalam penafsiran data ada 3 tujuan, yaitu : deskripsi semata-mata, deskripsi analitik atau teori substantif. Pada kegiatan ini, tujuan penafsiran data adalah deskripsi sematamata.

Pada tujuan deskripsi semata-mata, analisis menerima dan menggunakan teori dan 
rancangan organisasional yang telah ada dalam suatu disiplin. Dengan hasil analisis data, menemukan kategori-kategori dalam data. Atas dasar itu, penulis menysusunnya dengan jalan menghubungkan kategori-kategorinya ke dalam kerangka sistem kategori yang diperoleh dari data. Berdasar penafsiran data awal dari 3 (tiga) subjek ini, tim melakukan pengecekan ulang kepada para siswa kelas XI dengan cara FGD. Hasil FGD menemukan bahwa para siswa memiliki motivasi yang rendah, mengalami kecemasan, tidak percaya diri, dan belum memiliki goal setting. Berdasar hasil ini, tim melakukan kegiatan training motivasi di sekolah tersebut.

\section{HASIL DAN PEMBAHASAN}

Pelaksanaan kegiatan ini adalah di SMA Plus Dharma Karya. Berlokasi di Jalan Melawai XII no 2 Kav 207 A, Kebayoran Baru Jakarta Selatan, sekolah yang sudah beroperasi sejak tahun 1956 ini bernaung di bawah Yayasan Pendidikan Dharma Karya. Selain SMA Plus, yayasan ini juga memiliki SMK Dharma Karya yang bergerak di rumpun ekonomi. Sesuai dengan misi sekolah, keunggulan SMA Plus Dharma Karya antara lain (www.ypdharmakarya.com):

1. Membentuk peserta didik yang memiliki ketaqwaan terhadap Tuhan Yang Maha Esa

2. Mengabungkan Intelektual dan Budi pekerti

3. Membentuk peserta didik fasih membaca Al-Qur'an

Kegiatan yang dilaksanakan pada tanggal 16 Mei 2016 ini berjalan lancar tanpa kendala berarti. Seluruh rangkaian kegiatan disajikan dalam diagram di bawah ini :

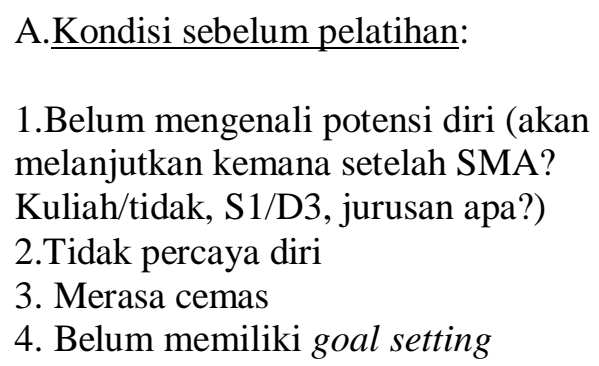

A. Kondisi sebelum pelatihan:

1.Belum mengenali potensi diri (akan melanjutkan kemana setelah SMA?

Kuliah/tidak, S1/D3, jurusan apa?)

2.Tidak percaya diri

3. Merasa cemas

4. Belum memiliki goal setting

\section{B. Treatment}

1.Tes Minat bakat

2. Temu-kenali diri

3. Menggali potensi

4. Sharing Session

5. Training Motivasi

6. Goal Setting

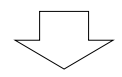

\section{Kondisi setelah pelatihan : \\ 1.Mengenali diri \\ 2. Mengenali potensi diri \\ 3. Merasa lebih percaya diri \\ 4. Rasa cemas berkurang \\ 5. Memiliki motivasi yang lebih tinggi}

\section{Kondisi Sebelum Pelatihan}

Berdasarkan informasi yang diperoleh melalui wawancara awal kepada alumni SMA Plus Dharma Karya serta wawancara dengan siswasiswi kelas XI diketahui bahwa kondisi mereka saat ini seperti yang tertera di box A. Hal ini dapat dijabarkan dalam kutipan hasil wawancara bersama para alumni:

"Waktu saya masih sekolah dulu, di usia usia segitu ya saya ngga tahu saya bisa apa. Tahunya ya pokoknya sekolah aja, kalo bisa dapat juara kelas biar orang tua seneng"

"Waaaahhh pas zaman itu mah saya tahunya cuma maen ama sekolah aja. Abis sekolah ya maen, bimbel - bimbel gitu juga ada sih"

"ngga inget ngapain aja pas sekolah dulu, rame-rame ama temen aja deh kayanya [...] belajar tambahan atau remed mah ada aja sih, yang penting nilai bagus"

"belum kepikiran mo ngapain, $\mathrm{Bu}$, yang penting sekolah, nilai bagus, orang tua seneng, udah"

"Ngga kepikiran mo ngapain. Kita anak swasta, ngga berani terlalu muluk-muluk, ngimpi masuk negeri. Pengen sih pengen, siapa sih yang ngga mau (kuliah di PTN)"

"saya ngga tahu sebenernya saya mau apa, yang penting lulus aja" 
"Suka keringetan juga sih kalo inget mo UN"

"Jangankan UN, Buuu, kadang ujian harian aja saya deg-degan"

"Waaahhh pasti deg-degan kalo inget $\mathrm{UN}, \mathrm{Bu}$. Siapa sih yang ngga takut"

Semua jawaban dari alumni menunjukkan bahwa saat mereka masih duduk di bangku kelas X dan XI, sudah mulai mengalami rasa cemas, tidak percaya diri, tidak mengenali potensi diri, dan belum memiliki goal setting. Meski ini sudah terjadi beberapa tahun sebelumnya, ternyata kondisi yang sama juga dialami oleh adik kelas mereka yang saat ini berada di kelas XI.

Jawaban dari para peserta kegiatan ini pun tidak jauh berbeda :

"yang penting lulus, nilai bagus, orang tua seneng, udah aja"

"yaaahh..., Bu. Yang penting mah lulus..."

"ga mikir, Bu. Kita liat nanti aja sebenernya saya mo ngapain, orang tua saya maunya saya ngapain"

"maunya sih ambil teknik di ITB, tapi ga tahu teknik apa"

"Pokoknya kalo kuliah di UGM saja, soalnya ayah saya lulusan sana [...] ngga tahu jurusan apa"

Sejumlah jawaban peserta menunjukkan bahwa mereka belum memiliki goal setting, apa yang menjadi goal, dan bagaimana cara yang mereka lakukan untuk mencapai goal. Saat ini goal mereka bisa dikatakan masih bersifat jangka pendek, yaitu hanya membahagiakan orangtua. Ketika goal mereka hanya bersifat jangka pendek, maka dampaknya adalah pada motivasi mereka yang tidak terlalu tinggi. Padahal jika goal mereka sudah jelas, tentunya akan lebih baik, karena mereka akan memiliki motivasi yang lebih baik untuk mencapainya. Contoh goal yang paling sederhana, misalnya akan melakukan apa setelah lulus (kuliah atau berkarir); jika memilih berkarir, di bidang apa; apakah buka usaha sendiri, ataukah melanjutkan usaha orang tua ataukah bekerja dengan orang lain; jika ingin kuliah, akan mengambil bidang apa; program D3 atau S1. Namun hal ini belum muncul meski ditanyakan berulang kali kepada para siswa dan siswi.

Sebenarnya belum munculnya goal para siswa dan siswi ini merupakan hal yang tidak terlalu mengherankan, mengingat mereka belum mengenali diri dan potensi mereka. Para siswa kurang memahami kemampuan dan potensi diri yang mereka miliki, termasuk kelebihan dan kekurangan yang ada dalam dirinya. Siswa juga belum memiliki rasa percaya diri terhadap potensi dan kompetensi yang dimiliki. Bisa jadi hal ini karena mereka merasa dari sekolah swasta yang biasa saja, dan tidak usah berharap terlalu tinggi untuk kelanjutan selulus SMA. Selain itu, siswa juga merasa cemas menjelang dan selama menghadapi ujian-ujian.

\section{Treatment / Pelaksanaan Pelatihan}

Berdasarkan hasil beberapa kali wawancara tersebut, tim merancang sejumlah treatment untuk diterapkan kepada para siswa dan siswi (kelompok target). Pelaksanaan kegiatan ini diawali dengan pelaksanaan tes minat bakat bagi para siswa. Hal ini dilakukan untuk membantu siswa mengenali minat dan bakat yang dimiliki. Melalui tes minat diharapkan siswa dapat memperoleh informasi dan mengoptimalkan potensi yang dimiliki. Kegiatan dilanjutkan dengan sharing session, dimana para siswa dilibatkan dalam diskusi mengenai hal-hal yang dapat menghambat dan mendukung pencapaian prestasi yang lebih optimal. Pemberian training Motivasi dan goal setting sebagai puncak kegiatan mendapatkan respon yang sangat baik dari para siswa.

\section{Kondisi Setelah Pelatihan}

Berdasarkan observasi dan wawancara kepada peserta setelah serangkaian kegiatan training selesai dilaksanakan, diperoleh data bahwa siswa memiliki informasi tambahan terkait potensi dan kompetensi yang dimiliki.

Sejumlah jawaban dari peserta adalah sebagai berikut :

"ngga nyangka ya, ternyata aku memang bakatnya di humas, padahal kemarin ayahku bilang kuliah di kedokteran aja [...] kalo gitu aku harus bilang ayah"

"hmm... aku suka (kegiatan trainingnya)". 
"mungkin besok-besok setelah aku lebih baik tidak terlalu ambisius untuk kuliah, aku kerja aja sama omku"

Selain itu, siswa juga merasa lebih percaya diri dan tidak terlalu cemas menghadapi ujian-ujian yang akan dihadapi.

"In syaa Allah sih pasti lulus dengan nilai yang bagus, tapi ngga akan kuliah kaya nya"

Selain itu, siswa juga merasa lebih termotivasi sehingga merasa mampu menentukan goal setting bagi pendidikan atau karir di jenjang berikutnya.

"Hidupku aku yang tentukan [...] aku mau sekolah di tempat yang bagus atau gimana, kalo aku males ya pasti hasilnya ngga bisa bahagia in orang tua [...] aku ingin bahagiain ibu karena bapak udah ngga ada"

"saya berangkat dari manapun, kalau saya tahu tujuan saya, saya bisa pikirin saya akan pake kendaraan apa dan lewat mana"

\section{KESIMPULAN}

Berdasarkan penjabaran yang telah disampaikan dapat disimpulkan beberapa hal, yaitu:

1. Siswa-siswa kelas XI Sekolah Menengah Atas memiliki sejumlah permasalahan sebelum menghadapi ujian akhir, terutama ujian nasional. Siswa-siswi cenderung merasa tidak percaya diri dan cemas, hal ini dikarenakan para siswa kurang mengenali diri dan memahami potensi dan kompetensi yang dimiliki.

2. Awalnya siswa belum memiliki goal setting yang jelas bagi kelanjutan pendidikan dan karir dimasa yang akan datang. Motivasi yang dimiliki siswa juga masih tergolong rendah.

Pemberian training motivasi membantu siswa dalam mengenali diri dan potensi yang dimiliki sehingga memudahkan siswa dalam menentukan goal setting bagi masa depannya.

\section{DAFTAR PUSTAKA}

[1] Badan Standar Nasional Pendidikan (BSNP). 2008. Prosedur Operasi Standar
(POS) Ujian Nasional (UN) Sekolah Menengah Atas/Madrasah Aliyah (SMA/MA) Tahun Pelajaran 2008/2009. Jakarta: Dinas Pendidikan Nasional.

[2] Marantika, L. 2003. Upaya Optimalisasi Kegiatan Belajar Mengajar. Bandung: Rosda Karya

[3] http://megapolitan.kompas.com/read/201 3/05/19/10053313/takut.tak.lulus.un.seor ang. siswi.gantung.diri. (Diakses pada 25 September 2015)

[4] http://www.edisicetak.joglosemar.co/beri ta/banyak-siswa-bunuh-diri-un-jalanterus-14289.html. (Diakses pada 25 September 2015)

[5] Johnson, D. W., \& Johnson, F. P. 2006. Joining Together, Group Theory and Group Skills. Boston: Pearson

[6] Boon, H. J. 2007. Low- and highachieving Australian secondary school students: Their parenting, motivations and academic achievement. Australian Psychologist, 42(3); 212 - 225

[7] Kirkpatrick, D. L., \& Kirkpatrick, J. D. 2007. Implementing the Four Levels: A Practical Guide for Effective Evaluation of Training Programs. San Fransisco: Berrett-Koehler Publishers

[8] Moleong, L.J. 2013. Metodologi Penelitian Kualitatif. Bandung : Remaja Rosda Karya

[9] Denzil, N.K \& Lincoln, Y.S. 2009. Handbook of Qualitative Research. Yogyakarta : Pustaka Pelajar

[10] Poerwandari, E.K. 2007. Pendekatan Kualitatif untuk Penelitian Perilaku Manusia. Jakarta: LPSP3 Fakultas Psikologi Universitas Indonesia

[11] Herdiansyah, H. 2010. Metodologi Penelitian Kualitatif untuk Ilmu-ilmu Sosial. Salemba Humanika. Jakarta

[12] Patton, M.Q. 2009. Metode Evaluasi Kualitatif. Yogyakarta : Pustaka Pelajar

[13] www.ypdharmakarya.com, (Diakses pada 17 Mei 2016) 